\title{
WEIGHTED COMPOSITION OPERATORS FROM DIRICHLET TYPE SPACES TO WEIGHTED TYPE SPACES
}

\author{
XiaOHONG Fu AND HaO Li
}

Abstract. The boundedness and compactness of weighted composition operators from Dirichlet type spaces to weighted type spaces on the unit ball of $\mathbb{C}^{n}$ are characterized in this paper.

Mathematics subject classification (2010): Primary 47B38; Secondary 46E15.

Keywords and phrases: Weighted composition operator, weighted type space, Dirichlet type space.

\section{REFERENCES}

[1] C. C. Cowen And B. D. MacCluer, Composition Operators on Spaces of Analytic Functions, Studies in Advanced Math., CRC Press, Boca Raton, 1995.

[2] X. FU AND X. ZHU, Weighted composition operators on some weighted spaces in the unit ball, Abstr. Appl. Anal. Vol. 2008, Article ID 605807, (2008), 8 pages.

[3] D. Gu, Weighted composition operators from generalized weighted Bergman spaces to weighted-type space, J. Inequal. Appl. Vol. 2008, Article ID 619525, (2008), 14 pages.

[4] P. HU, W. XU AND W. ZHANG, Boundedness of composition operators on $D_{\tau}$ spaces for $\tau>1$, Acta Math. Scientia, 20B (2000), 409-416.

[5] P. Hu AND J. Shi, Multipliers on Dirichlet-type spaces, Acta Math. Sinica (English series), 17 (2001), 263-272.

[6] P. Hu AND W. Zhang, A new characterization of Dirichlet type spaces on the unit ball of $\mathbb{C}^{n}$, J. Math. Anal. Appl. 259 (2001), 453-461.

[7] S. LI, Some new characterizations of Dirichlet type spaces on the unit ball of $\mathbb{C}^{n}, \mathrm{~J}$. Math. Anal. Appl. 324 (2006), 1073-1083.

[8] S. Li AND S. STEVIć, Weighted composition operators from $\alpha$-Bloch space to $H^{\infty}$ on the polydisk, Numer. Funct. Anal. Optim. 28 (7) (2007), 911-925.

[9] S. Li AND S. STEVIĆ, Weighted composition operators from $H^{\infty}$ to the Bloch space on the polydisc, Abstr. Appl. Anal. Vol. 2007, Article ID 48478, (2007), 12 pages.

[10] S. Li AND S. STEVIĆ, Weighted composition operators between $H^{\infty}$ and $\alpha$-Bloch spaces in the unit ball, Taiwanese J. Math. 12 (2008), 1625-1639.

[11] A. MonTES-RodríGUEZ, Weighted composition operators on weighted Banach spaces of analytic functions, J. London Math. Soc. 61 (2000), 872-884.

[12] S. Ohno, K. Stroethoff And R. Zhao, Weithted composition operators between Bloch type spaces, Rocky Mountain J. Math. 33 (2003), 191-215.

[13] H. J. SchwartZ, Composition operators on $H^{p}$, Thesis, University of Toledo 1969.

[14] A. Shields AND D. Williams, Bounded projections, duality, and multipliers in spaces of analytic functions, Trans. Amer. Math. Soc. 162 (1971), 287-302.

[15] S. STEvić, Composition operators between $H^{\infty}$ and the $\alpha$-Bloch spaces on the polydisc, Z. Anal. Anwend. 25 (4) (2006), 457-466.

[16] S. STEVIĆ, Weighted composition operators between mixed norm spaces and $H_{\alpha}^{\infty}$ spaces in the unit ball, J. Inequal. Appl. Vol 2007, Article ID 28629, (2007), 9 pages.

[17] S. STEVIĆ, Essential norms of weighted composition operators from the $\alpha$-Bloch space to a weightedtype space on the unit ball, Abstr. Appl. Anal. Vol. 2008, Aticle ID 279691, (2008), 10 pages.

[18] S. STEvić, Norm of weighted composition operators from Bloch space to $H_{\mu}^{\infty}$ on the unit ball, Ars. Combin. 88 (2008), 125-127. 
[19] S. STEVIĆ, On a new integral-type operator from the weighted Bergman space to the Bloch-type space on the unit ball, Discrete Dyn. Nat. Soc. Vol. 2008, Article ID 154263, (2008), 14 pages.

[20] S. Stević, On a new operator from $H^{\infty}$ to the Bloch-type space on the unit ball, Util. Math. 77 (2008), 257-263.

[21] S. STEVIĆ, Essential norms of weighted composition operators from the Bergman space to weightedtype spaces on the unit ball, Ars. Combin. 91 (2009), 391-400.

[22] S. STEVIĆ, Norm and essential norm of composition followed by differentiation from $\alpha$-Bloch spaces to $H_{\mu}^{\infty}$, Appl. Math. Comput. 207 (2009), 225-229.

[23] S. STEVIĆ, Norm of weighted composition operators from $\alpha$-Bloch spaces to weighted-type spaces, Appl. Math. Comput. 215 (2009), 818-820.

[24] S. STEVIĆ, On an integral-type operator from logarithmic Bloch-type and mixed-norm spaces to Bloch-type spaces, Nonlinear Anal. TMA 71 (2009), 6323-6342.

[25] S. STEVIĆ, On a new integral-type operator from the Bloch space to Bloch-type spaces on the unit ball, J. Math. Anal. Appl. 354 (2009), 426-434.

[26] S. STEVIĆ, Weighted composition operators from weighted Bergman spaces to weighted-type spaces on the unit ball, Appl. Math. Comput. 212 (2009), 499-504.

[27] S. STEVIĆ, Weighted differentiation composition operators from mixed-norm spaces to weighted-type spaces, Appl. Math. Comput. 211 (2009), 222-233.

[28] S. STEviĆ, Norm of an integral-type operator from Dirichlet to Bloch space on the unit disk, Util. Math. 83 (2010), 301-303.

[29] S. STEVIĆ, Norm and essential norm of an integral-type operator from the Dirichlet space to the Bloch-type space on the unit ball, Abstr. Appl. Anal. Vol. 2010, Article ID 134969, (2010), 9 pages.

[30] S. STEVIĆ, Weighted differentiation composition operators from $H^{\infty}$ and Bloch spaces to $n$th weigthed-type spaces on the unit disk, Appl. Math. Comput. 216 (2010), 3634-3641.

[31] S. STEVIĆ, Weighted iterated radial composition operators between some spaces of holomorphic functions on the unit ball, Abstr. Appl. Anal. 2010, Article ID 801264, (2010), 14 pages.

[32] S. STEVIĆ AND S. I. UEKI, Integral-type operators acting between weighted-type spaces on the unit ball, Appl. Math. Comput. 215 (2009), 2464-2471.

[33] M. WANG AND Y. LiU, Weighted composition operator between Bers-type spaces, Acta Math. Sci., 27A (2007), 665-671.

[34] X. ZHANG, Extended Cesaro operator on Dirichlet type spaces and Bloch type spaces on $\mathbb{C}^{n}$, Chin. Ann. Math. 26A (2005), 139-150.

[35] X. ZHU, Weighted composition operators from $F(p, q, s)$ spaces to $H_{\mu}^{\infty}$ spaces, Abstr. Appl. Anal. Vol. 2009, Article ID 290978, (2009), 12 pages. 